\title{
Keywords
}

Malawi; Sex work; Intimacy; Exchange; Sub-Saharan Africa

Studies of sex work have increasingly explored the forms of intimacy sex workers create and sustain. Although sensitive to the often brutal exploitation that sex workers experience, these studies emphasize the comingling between intimacy and the commodification of sex, realms that have been often portrayed as competing or mutually exclusive. The notion of exchange and intimacy as necessarily interwoven was systematically developed by Viviana Zelizer $(1989,1994,2005)$, demonstrating that the sites of economic transactions are often the same sites where intimacy is formed and sustained, forming a cultural intimacy-exchange nexus rather than different, competing, spheres. 
Cultural understandings, however, are far from unified (see, e.g., Swidler 2001). The ways actors navigate intimacy-exchange situations are often conflicted, and draw on multiple understandings of specific relational ties. In this article, we explore how sex workers in Malawi make sense of relationships with clients by drawing on two relational categories. One is a bounded and commodified understanding of exchange and intimacy, and the second a relational category that connotes premarital love and trust, the chibwenzi. As we demonstrate, in some situations the commodified is idealized, while in others, the more intimate chibwenzi becomes less "intimate" and is instead seen through the lenses of commodification.

This article thus uses Zelizer's framing of the nexus of intimacy and exchange as a methodological tool, an optic that enables us to follow the shifting meanings of relationships in post-colonial Africa. We then use this nexus to identify conflicting meanings of relationships between sex workers and their clients, and the articulations of these relationships (Laclau and Mouffe 1985). More specifically, we develop this insight in two directions-first, by showing that sex workers navigate multiple understandings of intimacy and exchange; second, by stressing the role that work pragmatics play in the articulation of such understandings. As we show in the conclusion, when seen in relation to the fraught history of gender relations in colonial and post-colonial Malawi, these findings also have direct implications for people who wish to understand — and perhaps intervene in - the complex lives of Malawian sex workers.

\section{Sex work, work, and intimacy}

Most analyses of sex work in sub-Saharan Africa still ignore the historical formation of sex work, or treat it as a purely economic occupational category. However, recent studies in subSaharan Africa and elsewhere have begun to pay attention to processes of sex workers' identity formation, as well as to historicize the specific experiences of sex workers.

For example, in her research on ukufandha sex workers in Soweto, South Africa, Wojcicki (2002) discovered that women who lived and worked in bars thought of themselves in ways that were quite distinct from (and superior to) the streetwalking "prostitutes," even though the ukufandha also exchanged sex for money. To accomplish this distinction, it was important to the ukufandha to present themselves as modern and respectable by using certain signposts, such as avoiding the streets, and not wearing short skirts, to distinguish themselves from other sex workers (ibid., p. 349). In a similar way, Trotter's $(2007,2008)$ ethnographic work with dockside sex workers in Cape Town, South Africa, showed how sex workers managed their interactions with potential clients by differentiating themselves from "street prostitutes." This difference was created both by stressing the different risks involved (2007), and, interactionally, by the extent to which they needed to perform emotion-work with clients (2008).

Approaching sex work in sub-Saharan Africa through historical lenses, Bujra (1975) described sex workers in colonial and post-colonial Nairobi as self-made entrepreneurs who took advantage of waves of urban migration. Although certainly pushed into the city and into sex work following experiences such as divorce and economic hardship, these women 
spoke of themselves as active agents, taking advantage of economic possibilities. White's (1990) exemplary study of sex work (also in Nairobi during the colonial era) further stresses how this historical context gave rise to different forms of sex work, spanning the gamut between women who simply exchanged money for sex and women who offered what they called "the comforts of home," providing migrants with an alternative household.

Outside of sub-Saharan Africa, a second stream in the sex work literature emphasizes the interactions between sex workers and their clients, and how these interactions are situated within institutional environments (see Bernstein 2007; Murphy and Venkatesh 2006; Weitzer 2000). Murphy and Venkatesh (2006) show how institutional differences in sex workespecially between "outdoor" and "indoor" work-affect sex workers' lives and careers. Many sex workers considered outdoor sex work dangerous and temporary; indoor sex workers saw their work as safer, since various measures could be drawn upon for protection. Partly as a result, and unlike outdoor sex workers, some women who worked at home considered it a "career job." Elizabeth Bernstein's (2007) Temporarily Yours shows similar patterns on a larger scale, demonstrating the relation between macro-economic trends and work pragmatics - as the economic situation in the global North moves towards mobile, "high-tech," neo-liberalism, indoor sex work is becoming more prevalent. Bernstein also shows that indoor sex workers are required to perform more emotion-work with some clients with whom they foster a "bounded intimacy," an intimacy that is at once real but that rarely crosses the boundaries of what sex workers understood as transactional sex.

Such analyses position sex work in the realm of the sociology of work and interaction. Although sex workers are often marginalized and victimized, their lives remain embedded in pragmatic challenges similar to those in other forms of labor-the categorization of clientele (Rosenthal and Peccei 2006), the gendered organization of work (Price 2008), and the role of emotion work as an inescapable part of the organization of gendered labor and exchange (Acker 1990; Hochschild 1983). As Becker (1982) argues in the context of art work, although such work pragmatics are often neglected, they have a profound influence on workers' understandings and the work they perform. This influence is not deterministic, as work pragmatics do not invariably force a specific understanding of actors' work. Yet such work pragmatics make certain interpretations more plausible than others, so that actors' understandings of their situation, and their courses of action, are shaped in patterned ways.

By locating sex work in its historical context and paying attention to work pragmatics, we can begin to map the interconnections between economic exchange and intimate relations, what Zelizer $(1989,1994,2005)$ calls the "connected lives" of participating actors. In other studies, such an approach allowed researchers to look at the gray areas between sex with clients, and sexual relationships which were defined as non-commercial (Barton 2006; Frank 1998; Kulick 1998). For example, Frank (1998) writes of strippers' experiences, and argues that stripping often requires fairly high levels of emotional involvement. Stripping in front of a "regular" must be enacted-as, but is often also experienced-as, going beyond the transactional. Similarly, in the South African context, Hunter $(2002,2005)$ shows that though men are expected to give their partners money, and though women have multiple partners, these women do not categorize themselves as sex workers, as the structure of gift exchange allows them to construct the relationship in other terms. ${ }^{1}$ 
In summary, we look at the historical transformations of gender relations and the pragmatics of sex work as ways to grasp the intertwining of sex work and other forms of exchange and intimacy in rural Malawi. Doing so, we further develop Zelizer's framework in two ways. Although her work has touched upon sex work and the institutions within which it is embedded (Zelizer 2005, pp. 119-129), Zelizer's analyses have generally treated institutions as sites where broader cultural understandings are brought to relief. In what follows, we first demonstrate how cultural understandings of intimacy are mediated and refracted by actors' pragmatic concerns within specific settings. Second, we show how-with multiple structures of exchange and intimacy always operating simultaneously (Swidler 2001)—sex workers make sense of the relationships with some clients through other historically emergent categories and sets of practices. Thus, instead of using Zelizer's approach to get at a coherent cultural narrative, we focus on the everyday navigations and complex articulations within which sex workers operate.

\section{Settings and methods}

Malawi is a small country, located in Africa's south-eastern corner. Most of its 14 million inhabitants live in rural areas, where the majority sustains its livelihoods through subsistence farming. Wage employment opportunities are scarce and under-employment extensive. At the time of the interviews (2006-2007), Malawi's GNI per capita was at $\$ 160$ (World Bank 2005), and it had the ninth-highest HIV prevalence rate in the world, with estimates of about $12 \%$ of Malawi's adult population being HIV positive (Government of Malawi 2004). Within Malawi, our study was conducted in the relatively poor Southern region, in the district of Balaka, where the predominant ethnic groups are Yao, Chewa, and Lomwe.

We chose Balaka for reasons both practical and substantive. As affiliates of a larger project, we had the opportunity to live and work in Balaka. The interviews for this study were conducted in the summers of 2006 and 2007 (with additional archival research done in the summer of 2010), when we stayed at a rest-house at what is known locally as the Mangochi Turnoff. The road at the Turnoff is formed by a sideways "T," with the straight arm being a main artery of the national road network running north to south, and with the road east connecting to the town of Mangochi, located on Lake Malawi. It is thus a main thoroughfare for people going to and from Malawi's major cities. The grounds surrounding the Turnoff teem with people, markets, bicycle taxis, rest houses, and food stalls.

Interviews were conducted with female sex workers living in the area surrounding the Turnoff. Because we are not fluent in the South's two main languages, ChiChewa and ChiYao, we employed two local Malawian female interviewers. The interviewers were in their early twenties, had had several years of qualitative interviewing experience with other research projects, and were then trained by one of the authors. Interviewers contacted sex workers with relative ease. There are a few well-known bars around the Turnoff, and the interviewers were able to approach the women working there. Once a few bargirls were interviewed, other bargirls and freelancers were contacted through a snowball method. After interviewers could not find additional sex workers in the Mangochi Turnoff, interviews were

\footnotetext{
${ }^{1}$ In this respect, this approach dovetails that developed by Mauss (1990 [1923-24]; see also, Bourdieu 1977).
} 
conducted in two adjacent areas, the Ulongwe trading center on the road to Mangochi and the town of Liwonde about three miles up north along the main road. Like the Mangochi Turnoff, Ulongwe and Liwonde are convenient locations for women from surrounding villages to seek employment as sex workers: markets are held twice per week, and a large number of food stalls, rest-houses, and small businesses operate daily, serving as a trading space for villagers and a resting place for internal migrants on their way home or to their working places.

Following Malawian categorizations, we interviewed two categories of sex workers"bargirls," who live at and work in bars, and "freelancers" (see also Kishindo 1995; Van Den Borne 2005). These terms are often said in English, and the ChiChewa term hule, (plural, mahule) translated as "prostitute," is sometimes used regarding both categories—although some interlocutors told us they would not feel comfortable referring to a bargirl as a hule. Bargirls live and work in bars, while freelancers are self-agents and are not tethered to a particular locale. We collected interviews with 18 bargirls and 20 freelancers, and interviewers weren't aware of other sex workers in the area. Interviews were also conducted by male interviewers with seven bar managers and owners in the same bars where the bargirls worked. All interviewees were compensated for their time. Interviews lasted between $45 \mathrm{~min}$ and $2 \mathrm{~h}$, and were recorded, translated, and fully transcribed. Although we rely mainly on these narratives, we also draw on the conversations the authors have had with local bar-goers and bargirls, and the time spent in the bars in which the study was conducted.

The interviews were loosely structured. Interviewers asked sex workers about three broad topics: (1) detailed descriptions of their life histories; (2) everyday life and work (including hours, work requirements, details about clients, and co-workers), and (3) how and when money is received from clients. When speaking with bar managers, interviewers inquired about employees, patterns of hiring, and reasons for firing bargirls. Otherwise, interviewers encouraged respondents to talk freely and to construct their own narratives and categories. We then coded the data using grounded theory precepts (Strauss and Corbin 1990). We thus moved from open coding, to axial coding and then theoretical coding — first coding within instances, then across instances, and lastly paying special attention to examples that could re-structure and change the emerging theoretical framework.

All the women interviewed were originally from rural villages (see also Kishindo 1995; Van den Borne 2005), and almost all were in their early twenties. In their life history narratives, both bargirls and freelancers spoke mostly of poverty and difficulty—many had lost one or both parents, and forced to fend for themselves. Fifteen of the women - six of the bargirls and nine of the freelancers-were married prior to becoming sex workers, but none was married at the time of the interview. Among those who were formerly married, women told of physical abuse or absent spouses. Without financial support, many women initially sought income through low-paid casual labor such as selling doughnuts (mandasi) or tomatoes on the market. Realizing that such jobs were insufficient, they then opted for sex work. Most of the women supported family members with their income, and would send money to their families monthly (in the case of bargirls) or more irregularly (in the case of freelancers). 
These characteristics were apparent for both bargirls and freelancers. There was no age difference between women in the two categories, and the only systematic difference we found in their lives prior to employment as sex workers was in contingencies of initial contact with sex work. Thus bargirls usually got into sex work through another bargirl or a bar manager, and freelancers were usually inducted into sex work by other freelancers. With the exception of two bargirls and two freelancers, the sex workers we interviewed did not move between categories.

This sampling frame has its limitations. Like other studies, we are studying the most visible sex workers- those whom interviewers found in local bars, and those whom bargirls and freelancers knew personally. It is unclear (in our study and in others), what happens to older sex workers. This study should be, therefore, thought of as a detailed focus on one stage in these women's life trajectories. Moreover, as bargirls' work is far more structured than freelancers', bargirls found it easier to answer questions about their daily routines. As a consequence, though we have rich data on some aspects of freelancers' lives, we know less about their daily routines.

\section{The chibwenzi relationship and sex work in southern Malawi}

In Malawi, a non-marital intimate relationship is known as chibwenzi (plural: zibwenzi), and is marked by the giving of money and gifts by men to their female sexual partners. As Poulin shows (2006, 2007), money exchange is a key signifier of the very existence of an intimate relationship external to marriage. Sex may not—and usually does notimmediately precede or follow the giving of money. Money is often given "just anytime," such as during an unexpected run-in at the local market, or ensuing from a man's receipt of wages from a stint of casual labor (Poulin 2007). Just as important, however, is the mutual understanding that the couple will engage in intercourse-were a woman to accept money from her chibwenzi without having sex with him, she would be chastised and possibly subjected to demands for his money back; were she to have intercourse without receiving money, she would be ridiculed, literally laughed at.

Even among couples who profess to each other their unbounded love, both women and men expect that transfers of cash will persist throughout the duration of the relationship. But although the economic aspect of such exchanges is undeniable, gifting is essential in the constitution of a specific "relational-tie" (Zelizer 2002). Money within chibwenzi relationships is both symbolic and material. Men use money for the practical purpose of having sex, but also to express love and demonstrate their worth. Women use the money to provide for certain "needs" such as soap, and for luxury items used to sustain or elevate their social status, but also to assess the degree of their chibwenzi's affection.

The origins of the contemporary chibwenzi relationship can be traced to pre-colonial gender relations. During the nineteenth century, the resident Mang' anja ethnic group, living in the area where the study was conducted, practiced a marriage system of brideservices, within which young, single men were obligated to provide labor to the family of a hoped-for wife for at least one agricultural season (Mandala 1984; see also Mitchell 1956 for a similar finding in the case of the Yao). Gifts were provided during this period to his prospective wife 
as well as her family as part of the courting and as a demonstration of his intentions (Collier and Rosaldo 1981). Brideservices were particularly important because upon marriage, men usually moved to their wives' compounds. Although the eldest brother within a kin group held sway over women in the family, women wielded much authority over daily life. Agricultural production was largely performed within the immediate family, with a relatively equal appropriation of labor efforts for women and men (Peters 1997); women were heads of villages, and local trade was open to both sexes (Mandala 1984).

These gender relations around agricultural production and village-level land use were notably resilient in the face of colonial policies and efforts by Christian and Islamic missionaries to create patriarchal-nuclear African families (Peters 1997). One such continuity can be seen in the relational-tie that gifting constituted. Writing about her fieldwork in the 1940s, Mair (1951, p. 109) describes how men were required to provide their prospective brides a gift known as chikole. Mair comments (ibid.) that "the relationship initiated by the gift is called bwenzi, "friendship," a word also used for extra-marital associations." This definition of bwenzi (later chibwenzi) was not external to the gift-the gift and its acceptance constituted the relationship itself. Thus, as late as the 1940s, gift exchange was part and parcel of courting.

Yet it would be a mistake to treat the contemporary chibwenzi relationship as an ossified remnant of a pre-colonial system. As Mandala (1984) noted, the economy of gender relations changed substantially in some realms of production. Unlike the agricultural sector, non-agricultural production such as fishing or craftsmanship was gender-specific, and vulnerable to changes driven by colonialism, particularly the expansion of markets, and the shift toward a cash economy. As an important source of income came to be wage labor on large tea, cotton and tobacco estates, men gained more economic and political power. Then, with the further colonial development of South Africa and Rhodesia, Malawian men increasingly migrated to work as miners in South Africa and the Copper Belt, leaving their wives behind to farm their lands. Although women thus retained their power in marriage patterns and village-level land use, the changes wrought by colonialism stripped them of some of the economic autonomy they had prior to the colonial era.

In some ways, Malawi's post-colonial history has seen a further worsening of women's position - with men still involved in migrant labor (albeit internal), and few incomegenerating and educational opportunities for women. Thus, although forms of social organization remained matrilineal and matrilocal, and gifts still play an important part in relationship-formation, colonial and post-colonial processes of modernization transformed the way gifts and money transfers were understood. First, transfers could now consist of small sums of money instead of a gift, and money today is more commonly given than are non-monetary gifts (see Poulin 2006). Second, in Malawi as elsewhere in South and Eastern Africa, men's geographical mobility associated with labor migration fostered extended periods of spousal separation, and more opportunities for non-marital sexual relationships that may never culminate in marriage. Thus, if in Mair's (1951) study the bwenzi was primarily a phase of courting, current use of the term chibwenzi in Malawi denotes a nonmarital relationship, and the possible move to marriage is much more tenuous. 
Like the transformations of the chibwenzi relationship, the rise of modern forms of sex work in southern Malawi is inextricably connected to the economic and political reconfigurations of gender relations, especially shifts in labor migration and the modernization of transportation. Although we have been unable to locate published accounts that describe sex work in colonial Nyasaland (Malawi's colonial name), given the historical literature on sex work in neighboring countries (see, e.g., Bujra 1975; Hunter 2005; White 1990), it is very doubtful that sex work in Malawi emerged only after independence. However, unlike the cases of Kenya or South Africa, as most Malawian men migrated out of Nyasaland during the colonial era, and the population was overwhelmingly rural-based (95\%), it is unlikely that sex workers in Malawi provided the same "comforts of home" that White (1990) describes in the case of Kenya. Many men were simply not there.

This situation changed in the post-colonial period. Since Malawi's independence in 1964, President Kamuzu Banda's government had been discouraging international migration. This sentiment was formalized in policy in 1974, when Banda implemented economic policies to build Malawi's cash-crop estate agriculture. Those policies proved effective: the number of Malawians working abroad dropped dramatically, and most Malawians in the late 1970s moved for work internally (Kydd and Christiansen 1982; Malawi Government 1977). Some returned men worked their own holdings, but many became wage employees in the newlydeveloped agricultural estates. That men returned to work within the country did little to rebalance the economy of gender inequalities - men were gone for most of the agricultural season and women still constituted the majority of subsistence farmers (Davison 1993).

Internal labor migration was facilitated by the construction of roads. About $35 \%$ of the development budget since independence has been spent on transportation infrastructure. Along the newly constructed roads, and especially the main arteries of transportation, small towns and trading centers sprung up. Aided in the 1980s by micro-credits supported by NGOs and the Malawian government (Englund 2002), these centers serve internal migrants and carriers, offering markets, rest-houses, restaurants, and bars. The Mangochi Turnoff, where this study was conducted, is paradigmatic of these changes. It is situated on the Tjunction of two of Malawi' s most traveled routes, connecting the large southern cities of Zomba and Blantyre to the capital, Lilongwe, and branching off to Mangochi, the main city at the south of Lake Malawi. With rural-urban migration picking up pace since democratization in 1994 (Englund 2002), such roads became even more important, linking people not only to other rural areas, but also to urban centers. Consequently, traffic levels along this route nearly doubled over a 20 -year span, rising from a daily average of 1,450 in 1976 to 2,900 vehicles in 1997 (Malawi roads and transportation bureau 1986, 1997).

Sustained rural to rural internal labor migration, increases in urbanization, and continued restriction of income-generating opportunities for women in the 1990s has meant a mounting of pressures and opportunities for women to move into sex work. Not infrequently, Malawian women today need to supplement subsistence farming with casual labor. The growing number of trading centers and roads-side towns give women places to sell their produce, or work in the restaurants, shops, and bars that had proliferated at least since the 1980s (Forster 2000: 4; see also Hirschmann and Vaughan 1983). Although working in bars does not necessarily require sex work, these locations also enabled women, and often pushed 
them, towards sex work (Forster 2000). More recently, the 2001-2002 and 2008 famines in southern Malawi exacerbated both women's necessity to sell their labor in the trading centers and the draw of sex work as a way to make ends meet and to support children and relatives (Bryceson 2006).

\section{Work pragmatics in the Malawian sex work economy}

The historical account above pushes us to think about sex work in the context of a historically shifting configuration of gender relationships. Sex work, however, was constructed in multiple ways, with bars requiring "bargirl" workers, on the one hand, and forms of "freelance" sex work, on the other. These different forms of sex work, and the different work pragmatics they entail, are important both for sex workers' labor, and for the ways they understand their relationships with clients. We thus start by describing the routines of these sex workers - what their days look like and how they narrate the practices of sex work they are engaged in.

\section{Bargirls' organization of work}

Chibuku is a maize beer brewed in Zambia, served in paper-made cartons that require shaking and cutting. In the southern region of Malawi, bargirls usually work either in downscale bars where mostly Chibuku is served-Chibuku bars-or in slightly more upscale bars where other beer (namely, Carlsberg) may be served as well. These are usually small establishments. The bar area consists of a small counter or bar and a refrigerator that stores the drinks. Wooden bar stools align the bar, and additional seating can typically be found in the form of plastic tables and chairs. A sound system playing the latest musical hits from Malawi, Zambia, and the United States is almost mandatory, as small groups of customers sit and chat, often having to shout over the sound system. Other details vary, but often include a pool table or a television set.

Bargirls perform dual occupational roles as both waitresses and sex workers, between the semi-formal salaried economy and informal sex work. Waitressing offers a monthly salary, while sex work earns the women supplemental income. Waitressing entails an arduous schedule. Work days begin at about 6:30-7:30 am when bargirls set up the bar, and end somewhere between midnight and 3:00 am, after closing, to clean up. Bargirls usually work in two shifts, where one or two bargirls open the bar in the morning, and another team takes over at noon, with both joining forces after a short afternoon rest, between 6:00-6:30 pm. Throughout their shifts, the women perform waitressing duties, serving drinks and snacks, and opening Chibuku cartons for patrons. During the lulls in the work, they often sit together around a table, sometimes having a beer themselves. Salaries mostly depend upon workseniority; veteran bargirls may earn K1,000 more than a newcomer, making up to K2,500, about $\$ 17$ a month. With a GNI of $\$ 160$ a year, this is not a high salary in peri-urban Malawi, but more than most sellers in the market expect to make. ${ }^{2}$

Bargirls usually live in small rooming complexes behind the bar premises. Rooms are usually very small: a bed, a small table, and little else. These rooms are either supplied free

\footnotetext{
${ }^{2}$ In July-September 2006, when these interviews were conducted, one US dollar was equal to 141 Malawian Kwacha.
} 
by the owner or rented at a low cost. Only two of the 18 bargirls we interviewed lived in rented apartments elsewhere. Bargirls' relations with co-workers thus tend to extend into friendship ties, and the bar becomes the main site of sociality even when they are not working.

Like bartenders in other places, bargirls are expected to flirt and engage in conversation with clients in order to promote sales. Conducting this kind of gendered emotional labor (Hochshild 1983) was invariably described as part of the work, even in the two cases of bargirls who claimed they did not have sex with patrons. However, for almost all bargirls, interactions with patrons were often a prelude to sex, and patrons and managers alike expected bargirls to be open to sexual proposals.

In many cases, chatting and flirting with patrons functions to test the ground before deciding to have a sexual transaction; bargirls assess whether a potential client is safe or desirable (see also Trotter 2007, 2008). To minimize risk of being swindled, bargirls assess signs of wealth and status. Such signs include whether the client is well dressed, buys large quantities of chibuku, or invites others for drinks. As this woman tells the interviewer:

I look for smart guys [which I recognize by] the way they dress. And you see if you can go with him, how much will he give you. And [by] the way he buys beer you can tell. (...) He [might] buy lots of beer, we are the ones who serve beer and we know who is paying the bill.

After evaluating the patron, bargirls will bargain for a price. Bargaining includes perceptions of affluence, but also length of the proposed sexual encounter. Bargirls (as well as freelancers) distinguish between what they call "short time"- usually defined as a few minutes of intercourse in the bargirl's room—and "long time," understood to be an entire night in a rest-house. They charge anything between K150 and K500 for "short time" and up to K1000 for the whole night.

Combining the demands of bar-work with sex work presents a pragmatic problem: bargirls are expected to have sex with clients, but also required to keep up with extensive beerserving and table-cleaning work. Although managers expect bargirls to have sex with patrons, and to be away from the bar from time to time, if bargirls are absent too often, they risk losing their job. The client selection process is thus critical as the number of clients a woman may take in an evening is limited, and bargirls do not usually have more than two clients per night.

If the work environment forces bargirls to be selective, a predictable monthly salary means that bargirls can (and do) opt out of sexual exchanges when no patron seems suitable, when they are sick, or sometimes when menstruating. Bargirls enjoy an additional benefit of being choosy - assessing personal risk with a questionable potential client. Except for two women, bargirls all claimed to use condoms at all times, resisting even when clients offered more money to "go plain." 3 Bargirls also often said they avoided a thin looking client, a local sign used to identify people with AIDS.

While bargirls had well-defined obligations in the bar, managers and bar owners had their own obligations to the bargirls. In none of the cases did either bargirls or managers report 
taking any percentage of the bargirls' earnings from sex work. Bar managers also permit bargirls to take leave from work when ill, as acknowledged by both bargirls and bar managers interviewed. If the illness is not too long, managers maintained they do not deduct sick-days from an employee's salary, provided her co-workers take over her responsibilities. Assuming illnesses are usually sexually transmitted, one manager explained, "we don't deduct, this is not her fault.... The problem is clear to us."

In these ways, bar managers view themselves as lenient, while at the same time exercising tight control over bargirls. These dual qualities of patronage and control have the practical effect of protecting bargirls should the occasion call for it. As one bargirl recounts about a co-worker:

I remember one day she was working and serving customers beer. One of the customers proposed her [asked her to have sex with him] and she refused. Then he started bullying her and the boss heard, and he took the customer to the police station. At the end the customer was imprisoned and stayed three days in the cell.

Thus, on the one hand, bargirls' lives are tightly regulated, and the possibility of accumulating larger sums of income through multiple clients is thwarted. On the other hand, this makes it possible for them to construct a view of themselves in which they have much personal control. Guaranteed a livable monthly income and some protection from clients' rape and violence, bargirls may opt out of engaging in intercourse with a specific client or on a particular evening.

\section{Freelancers' organization of work}

Freelancers lack the kind of institutional setting that defined the working lives of bargirls. Whereas bargirls' lives revolves around the bar as workplace and, in effect, total institution (Goffman 1961), freelancers are self-employed and self-reliant. None of the freelancers we interviewed worked through an intermediary, a "pimp," or manager. Not tethered to a specific place, freelancers moved from one locale to another, seeking clients. As opposed to bargirls, freelancers rented apartments or houses in the town or trading center, and relied heavily on exchanges of sex for money.

All the freelancers we interviewed actually went to bars to find customers. On a night in the bar it was sometimes hard to determine who was a bargirl and who was a freelancer.

Although bargirls work in the bars, they do not control access to them-and managers unanimously said that freelancers are welcome; their presence increases the attractiveness of the owners' establishments to male patrons or would-be patrons. Surprisingly, none of the freelancers or bargirls noted any tensions between the categories, although the freelancers are on the bargirls' "turf." This was both because bargirls actually had sex with few clients in a relatively bustling setting and because freelancers made sure they were "useful" when at the bar. As one freelancer pointed out, when looking for clients in the bar, she helps the bargirls serve drinks, not so much out of camaraderie but to gain access to potential patrons:

\footnotetext{
${ }^{3}$ We cannot know whether bargirls are reporting condom use because this is expected given the AIDS epidemic and a plethora of targeted messages regarding condom use (see van den Borne 2007). However, men we met sometimes joked about how bargirls demand condom use (see also Tavory and Swidler 2009).
} 
When I get there, I start by dancing to attract men to make them invite me to where they are sitting. I help cutting chibuku and serving sometimes, to make the men notice you. And that is when you find somebody to take you to a rest house or wherever.

Yet, as this woman implies, whereas bargirls work from morning until night, freelancers come to the bar in the evening. During the day freelancers either rest or engage in some other money-generating activities such as selling in the market or working in small retail businesses - thus straddling, in different ways, the line between the semi-formal and the informal economy. Moreover, while bargirls invariably find their clients at the bar, freelancers talked of the bar as only one of many possible sites. When the "market" (as they call edit) dries up in one area, freelancers move to another locale. These locales may be close by, such as the next market area or town, but may be further away, such as the cities of Blantyre, Zomba, or Lilongwe, a few hours away by minibus.

Rather than being narrated as an inconvenience, most freelancers said that this mobility provided freedom that bargirls lacked. This distinction was important to many freelancers:

I have control of my own time while the bargirls work under the control of their managers. And we [mahule] move from different places like Mangochi, Mangochi Turnoff, Blantyre, or anywhere we want to go, because we have our own control while bargirls just stay at the same bar each and every day serve the customers. We don't do that.

Not tied to any supervisor, freelancers made sense of their work through their perceived ability to work whenever and wherever they wanted. And yet, as could be expected from the literature regarding "streetwalkers" in the United States, Europe, and South Africa (Murphy and Venkatesh 2006; Trotter 2007; Weitzer 2000), this freedom was beset with risks. Almost all the freelancers told of situations in which clients became violent or attempted to leave without paying. Moreover, freelancers were not always able to secure work. Although some reported having sex with a higher number of clients per night, most freelancers reported having an average of two to three clients per night, only one more client than did the average bargirl. Without a social safety-net to fall upon when unable to work, their situation was precarious:

I: What if you all come back without money? What do you do?

R: That means no food, so what else can we do? We just try hard the next day.

Thus, whereas bargirls could count on monthly income and shelter, freelancers were more dependent upon daily fluctuations, unable to request a loan from managers or make monthly plans. This was also translated in freelancers' narratives into a diminished bargaining power: no work may literally mean "no food." Thus, whereas all bargirls said they choose clients carefully, at least some freelancers interviewed said they take any offer. As one reported "I have no choice, anybody can take me, whoever, I just don't care."

In summary, although freelancers could engage in sex work with more clients, and often earned higher incomes than bargirls per-night, this income was fluctuating and unpredictable. Additionally, receiving daily cash, and usually supporting relatives in rural 
areas (which bargirls also did), meant that freelancers spent their daily income rather than saving it for rainy days (see Swidler and Watkins 2007). This, in turn, meant that their greater freedom in terms of work management and physical mobility was offset by less power to negotiate with potential clients.

\section{“Chibwenzi" relationships, exchange, and the construction of intimacies}

The sections above provide what we see as the two contextual environments that are important for understanding the ways sex workers understand their relations with clients. First, such understandings are located in a historical context in which pre-marital chibwenzi relationships include exchanges of money and sex, and that also seems to be more precarious and couple oriented - a way to connect young people's lives rather than to connect households. Second, differences in the mundane work pragmatics of freelancers and bargirls allow them to construct different understandings of freedom and constraint. Bargirls described long hours and tight management control, yet construct themselves as having more power to select clients. For freelancers, the narrative of freedom and constraint was inverted. Freelancers all said that the ability to be masters of their own time and working place was important in preferring their work over that of bargirls. But although they said they earned more money, freelancers also described less ability to negotiate with clients.

We now move to the questions we began with-how historically situated understandings of gender relations and work pragmatics come together to sustain particular forms of intimacy and exchange. The ubiquity of money exchanges in chibwenzi relationships means that the work of bargirls and freelancers was at once far removed and closely related to "non sex work" intimacies-and as we show, distinctions between regulars and chibwenzi relationships were often blurred. Such understandings were further shaped by sex workers' work pragmatics, resulting in differences in the prevalence and the understandings of intimate relationships. Of 18 bargirls, 12 reported being in a chibwenzi relationship at the time of the interview. Five did not, and in one case it was unclear whether the relationship with a man was chibwenzi, or whether he was a client. Of twenty freelancers interviewed, only seven had chibwenzi, eight did not, and five gave contradictory responses during the interview.

But, as we show below, these differences tell only part of the story. It is not only that bargirls and freelancers have different "windows of opportunity" for slipping between different understandings of gendered exchange and intimacy, but that these were articulated differently through these pragmatic lenses. The difference in prevalence was thus further translated into differing ways in which sex workers understood and experienced their chibwenzi relationships.

\section{Bargirls and regulars}

Bargirls' work obligations typically mean that they could be found in the same place evening after evening. As bars are also loci of sociability, bargirls often interact with the same habitués, and conduct sex work with men who may become "regulars." These facts were crucial in terms of chibwenzi relationship formation. In fact, of the twelve bargirls who 
reported having a chibwenzi, nine said they met him at the bar, where he "proposed" a chibwenzi relationship.

A bargirl's acceptance has implications for her availability, her expectations of aid and care, and for the exchange structure she has with the chibwenzi. All bargirls said that they immediately attend to their chibwenzi whenever he comes, leaving potential clients, sometimes asking managers or other bargirls to warn them if they see their chibwenzi coming, to avoid scenes of jealousy and possessiveness. In a narrow sense, from the vantage point of the client, an acceptance of a chibwenzi proposal ensures that the bargirl will be available. As one bargirl tells of the transition of a regular to chibwenzi:

He asked me to be his chibwenzi so that whenever he comes I should be accepting him when he asks me for "long time." Since I saw that he was a good client I accepted him and whenever he comes here I do accept him because he is my chibwenzi and I do refuse other clients for him.

In this excerpt, the chibwenzi relationship seems to be understood by the bargirl as an agreement of preferential treatment. The entry into the relationship is couched in the language of rational calculation. The client's chibwenzi request is answered because he was a "good client," and the consequences are that she "accepts" him whenever he comes.

In most bargirls' narratives, however, the expectations from the relationship change dramatically when it becomes a chibwenzi. Although they are both still steeped in relations of exchange, the rules are transformed. First, a chibwenzi is expected not only to give bargirls money, but to provide non-monetary gifts, ranging from a bag of maize to a pair of jeans or a yogurt. These modified exchanges are part of a pattern of intimacy that includes caring for bargirls when ill, but also more intangible intimacies. As one woman described her relationship:

He does take care of me when I am sick, which the clients can't do. He also does visit me regularly and he gives me things that I want, whether having sex or not, while the clients just come to quench the problems of sex. When he is available I don't allow other clients because he is the only one who cares for me.

Although the worth of the gifts was mentioned in a few interviews, the fact that the chibwenzi thought of the bargirl when he was away seemed more important. Like chibwenzi relationships in other, non-sex work realms (Poulin 2007), a critically important characterization of the relationship was that the man did not always give the bargirl money when he visited her, nor always had sex with her when he brought gifts. The timing of money exchange in relation to sex was left vague (Bourdieu 1977), and this under-defined quality was drawn upon as a crucial resource to distinguish one's client as a chibwenzi. In fact, two of the bargirls said they had stopped conducting sex work after the chibwenzi relationship solidified, and two others told the interviewers that they lie to their chibwenzi, telling them they stopped conducting sex work, and relying on their manager or friends to cover for them while they "do short time in secret."

Bargirls thus used the timing and quality of the exchanges - the when and the what - to distinguish between regulars and a chibwenzi. But this distinction was also difficult to 
maintain coherently. As one example of such slippage, note that at the end of the interview excerpt above, the bargirl says she does not allow "other clients" when the chibwenzi comes, implying that although he may be different, he was still part of this collective. This blurring of categories was actually a hallmark of most interviews, where the chibwenzi was simultaneously spoken of as a preferred client and an intimate and completely noncommodified relationship. Not only did "regular" relationships sometimes transition into chibwenzi relationships-which may not be surprising given the institutional setting (see also Frank 1998) - but the very differentiation between customers and a chibwenzi was vague, and bargirls often (though not always) conflated these two membership categories.

These blurred boundaries between "regular" and "chibwenzi" point to the ways in which different understandings of intimacy and exchange are articulated in practice (Laclau and Mouffe 1985). Instead of positing that relational ties correspond with a specific understanding of intimacy and exchange, the relationship with the regular/chibwenzi is broken down into different practices of care and exchange- a bundle of practices and logics rather than a unified category. The same relationship may be seen as a "regular client" relationship, as a chibwenzi, or both, according to the situational context of action and narrative. Thus, in terms of exchange, though the chibwenzi did not have to pay for sex, some bargirls said they asked him to give her money regularly. Simultaneously, some bargirls extended "credit" for some men who came regularly, without treating them as chibwenzi, again making the differentiation between the categories slippery.

\section{Freelancers: distancing the chibwenzi}

As we demonstrated above, the ability to do "whatever you want," as one freelancer put it, was important for freelancers even in cases in which they conceded that the patronage of bar management meant better physical and financial protection. In fact, two freelancers not only differentiated their situation from that of bargirls, but compared themselves to women in rural Malawi who do not take part in sex work. Thus, one interviewee attempted to convince the interviewer to join the trade, and another commented that her living conditions as a freelancer were much better than they were prior to her engagement with sex work, when she was married in a nearby village.

The importance of self reliance was visible in the way that many freelancers spoke about both their chibwenzi relationships and about their clients. Thus, whereas seven of the freelancers had a chibwenzi, most freelancers had neither a regular nor a chibwenzi, or (in five of the cases) gave contradictory statements about their relationships, referring either to the same person as client and as chibwenzi, or to multiple zibwenzi, something which very rarely occurs in other settings (Poulin 2006). If bargirls understood regular clients in terms of the chibwenzi relationship, freelancers constituted the chibwenzi relationship in terms of sex work-so that understandings of sex work and chibwenzi were mutually constitutive.

Thus, freelancers who said they did not have a chibwenzi and those with contradictory statements described regular clients who saw themselves as their chibwenzi in a far less idealized way compared to any of the bargirls. Moreover, some of the freelancers who did have a chibwenzi appeared to be quite sarcastic about their relationship. Despite (and perhaps even because of) the reduced capacity for client selection, freelancers underlined 
their autonomy and power within such relations. In the excerpt below, the interviewee describes how she uses a man who she herself had termed her chibwenzi seconds before:

If he comes most of the time he gives me 1,000 Kwacha, and that is why he is important to me. He gives me money to buy what I need, and [when] sometimes he visits me and finds that I have nothing he goes to the market and buys me relish and groceries. He buys me all that. I prepare lunch or dinner and he doesn't eat. The funny thing is I share this food with other men [who are] my clients, [while] the one who buys this food is gone.

First, the interviewee posits that the reason for the "importance" of chibwenzi is that he pays well. Then, like bargirls, she differentiates this transaction from transactions with other clients: the chibwenzi buys her gifts; she, in turn, makes him a meal, another well established sign of intimacy. But as she continues her narrative, the similarity breaks down. Rather than idealizing the relationship, she stresses how she dishes out the food he just gave her to short term clients who come when he is away. By giving the food away to other men she dismisses and subverts the relational meaning of the gift, rendering it impersonal; the chibwenzi is situational, and as he leaves the significance of the gift is transformed. This narrative may seem to echo the narratives of sex workers in the United States which Bernstein (2007) characterizes as a bounded intimacy. However, in freelancers' narratives, the intimacy is not only bounded, but also distanced-a subverted intimacy.

Freelancers explicitly described themselves as controlling the significance of the relationship, a stance that was further tied to the number of concurrent relationships they entertained. This, of course, is possible only because of their institutional freedom: being more mobile, they could manage multiple "chibwenzi" relationships. Whereas bargirls could not maintain more than one relationship, as their chibwenzi could always find them, freelancers could juggle such relationships quite easily. When interviewers asked some of the freelancers, how many zibwenzi they had, one answered that "I have four serious ones. The others I just sleep with," and another that she has many suitors, but that "there are two who are clinging to me." Thus, as opposed to bargirls, most freelancers without zibwenzi (as well as those who gave contradictory responses) also said they did not want a chibwenzi, and they were better off for it—both financially and emotionally.

This position, however, should not be taken as a celebratory sex-revolt against patriarchy. This is for two reasons. First, some of the freelancers did describe a chibwenzi relationship that was narrated as a more idealized relationship of trust, with the possibility of marriage looming over it (in six cases), or said they craved such a relationship to take them away from sex work (in another two). Second, the self-reliant position was itself often conflicted. In the following excerpt, the self reliant position and the interviewee's emphasis that she "has fun" is marred by statements in which her position is one of suspicion and pain:

I really don't want to involve myself in another serious relationship. I don't feel like having a steady boyfriend anymore. I feel like all men are the same. I have them every day. I don't trust them. That's why I just like to go some place and have fun, meet somebody, we have sex, [he] pays me, he goes and I go. Not that I will be seeing him again. I don't like that. It's really hard. 
In summary, although a few freelancers described rewarding relationships with their chibwenzi, freelancers' narrative of control over their own work was extended to define the way they could approach exchanges and potential transformations of sex work into other intimacies. It is not only that relationships with regular clients were articulated through the chibwenzi frame, but that relationship with these zibwenzi were then re-articulated through sex work. Freelancers' narratives of independence thus allowed them to re-frame and distance themselves from the relationships they were engaged in - to subvert practices of chibwenzi intimacy either practically or discursively.

\section{Discussion and conclusions}

This article provides a window into the ways in which sex workers in Malawi navigate and articulate multiple understandings of intimacy and exchange. We start with Zelizer's insight, urging us to think of monetary exchange and intimacy as analytically and empirically intertwined rather than as separate or contending spheres (e.g., Zelizer 2005). However, instead of treating this insight as the end-point and use the Malawian case as an exemplification, we use it as a starting point. We then specify the historical transformations of gender relations, as well as the pragmatic, institutional dimensions within which sex workers actively navigate the exchange-intimacy nexus.

Doing so emphasizes that intimacy and exchange in Malawi cannot be understood in the abstract, but only in relation to specific and shifting histories of gender relations, as they were (and still are) constructed through colonial and post-colonial Africa (see also Hunter 2005; White 1990). If the theories we begin with provide us with an optic through which to make sense of intimacy and exchange, it is the local flux of categories and gendered economies that provides the lenses through which sex workers understood their relationships.

Adopting this perspective allows us to appreciate that gender relations in southern Malawi are far from being a unitary or coherent set of practices and understandings. Instead of assuming a single cultural logic, some of the most interesting parts of sex workers' narratives were concerned exactly with the ways they navigated and articulated overlapping and conflicting expectations (see also Swidler 2001). These gendered expectations were further shaped by local work pragmatics. Especially important in our case were the transformations of pre-colonial practices of brideservices, where the chibwenzi relationship entailed a semi-formalized pattern of exchange between intimate partners. Thus, the relationships bargirls constructed with regular clients could easily blur into the chibwenzi relationship; some freelancers also understood their relationships with regulars in terms of the chibwenzi, but then subverted these expectations by articulating chibwenzi-practices through the radically bounded intimacy of commodified sex work.

Attention to the local context - both in its historical permutations and in its lived presentfocuses the questions that need to be asked to understand the intertwining of intimacy and exchange. As Zelizer stresses throughout her work (Zelizer 1989, 1994, 2005), the historically and culturally specific understandings of intimacy are crucial for making sense of the local patterns of such intertwining. Institutions and everyday pragmatics, as many 
researchers have emphasized (see, e.g. Barton 2006; Bernstein 2007; Murphy and Venkatesh 2006), are important sites for shaping the situated understandings of such intertwining. As we argue in this article, an account that appreciates the historical emergence of multiple logics of intimacy and exchange allows us to see that local work pragmatics not only mediate local understandings of intimacy and exchange, but articulate these multiple cultural logics in new ways. It is not only that sex workers understood some of their clients through the category of chibwenzi, but that what the category meant was different in bargirls' and freelancers' narratives.

Understanding sex workers' patterns of intimacy and exchange as emerging from their specific histories is especially important in the context of the world of foreign aid and largescale programs initiated by the UN, IMF, and other large INGOs. In view of the catastrophic repercussions of the AIDS epidemic in sub-Saharan Africa, sex workers have been targeted for a plethora of interventions, educational efforts, and missionizing attempts. Certainly, sex workers may respond to economic (and political) turmoil by having more sex with clients, or by foregoing the use of condoms, as work in Kenya has recently found (Dupas and Robinson 2011). Yet AIDS-specific interventions should take care not to overemphasize abstracted economic incentives and attempts at "education," while overlooking the locally constructed ways in which sex workers already understand their relationships. Sex workers and their interactions with their male clients in Malawi took their present form in relation to political and cultural specificities. NGOs should consider how these women interpret their own lives when designing and implementing programs. Doing so would not only allow for a more empathetic understanding of sex workers' lives (though this, in itself, is important), but because without doing so many findings, and subsequent practical interventions, are suspect.

\section{Acknowledgments}

The authors would like to thank Nicole Angotti, Adam Ashforth, Rebecca Emigh, Steve Epstein, Nahoko Kameo, Alexandra Murphy, Bill Roy, Abigail Saguy, Michael Stambolis, Ann Swidler, Stefan Timmermans, Lynne Zucker, and the UCLA historical sociology group for reading and commenting on earlier drafts of this article. Susan Watkins provided unerringly patient feedback and support throughout the project. Their criticisms and suggestions have been invaluable.

\section{Biographies}

Iddo Tavory is Assistant Professor of Sociology at The New School for Social Research. He is currently transforming his dissertation work-an ethnography of an Orthodox Jewish neighborhood in Los Angeles-into a book. He is also continuing his research in Malawi, working on AIDS humor in everyday life, as well as the careers of NGO volunteers in comparative perspective. Drawing on observations in these empirical fieldsites, he has also written about the logic of qualitative methods and theoretical accounts of morality, flirtation, and temporality in interaction. His work has been published, among other places, in the ASR, Theory and Society, Sociological Theory, Ethnography, and Sociology of Religion.

Michelle Poulin is Assistant Professor of Sociology at the University of North Texas. She is the author of several articles in social interaction, cultural sociology, and gender and the family, especially in sub-Saharan Africa, including, "Reporting on First Sexual Experience: The Importance of Interviewer-Respondent Interaction" (2010). One of her current projects 
in Malawi addresses how international human rights rhetoric is being adopted and modified locally, in the domain of marriage.

\section{References}

Acker J. Hierarchies, jobs, bodies: a theory of gendered organizations. Gender and Society. 1990; 4(2): 139-158.

Barton, B. Stripped: Inside the lives of exotic dancers. New York: New York University Press; 2006.

Becker, HS. Artworlds. Berkeley: University of California Press; 1982.

Bernstein, E. Temporarily yours: Sexual commerce in post-industrial culture. Chicago: University of Chicago Press; 2007.

Bourdieu, P. Outline of a theory of practice. Cambridge: Cambridge University Press; 1977.

Bryceson DF. Ganyu casual labour, Famine and HIV/AIDS in rural Malawi: causality and casualty. Journal of Modern African Studies. 2006; 44(2):173-202.

Bujra JM. Women entrepreneurs of early Nairobi. Canadian Journal of African Studies. 1975; 2:213234.

Collier, JF., Rosaldo, MZ. Politics and gender in simple societies. In: Ortner, SB., Whitehead, H., editors. Sexual meanings: The cultural construction of gender and sexuality. Cambridge: Cambridge University Press; 1981. p. 275-329.

Davison J. Tenacious women: clinging to Banja household production in the face of changing gender relations in Malawi. Journal of Southern African Studies. 1993; 19(3):405-421.

Dupas, P., Robinson, J. Savings Constraints and Microenterprise Development: Evidence from a Field Experiment in Kenya. 2011. NBER Working Paper, \#14693

Englund $\mathrm{H}$. The village in the city, the city in the village: migrants in Lilongwe. Journal of Southern African Studies. 2002; 28(1):135-152.

Forster P. Prostitution in Malawi and the HIV/AIDS risk. Nordic Journal of African Studies. 2000; 9(1):1-19.

Frank K. The production of identity and the negotiation of intimacy in a 'gentleman's club. Sexualities. 1998; 1(2):175-201.

Goffman, E. Asylums: Essays on the social situation of mental patients and other inmates. New York: Doubleday and Anchor; 1961.

Government of Malawi. Malawi demographic and health survey. Zomba: Government Printer; 1977.

Government of Malawi. Transport statistics. Malawi: National Statistical Office; 1986.

Government of Malawi. Transport statistics. Malawi: National Statistical Office; 1997.

Government of Malawi. Malawi demographic and health survey. Zomba: Government Printer; 2004.

Hirschmann D, Vaughan M. Food production and income generation in a matrilineal society: rural women in Malawi. Journal of Southern African Studies. 1983; 10:86-99.

Hochschild, AR. The managed heart: Commercialization of human feeling. Berkeley: California University Press; 1983.

Hunter M. The materiality of everyday sex: thinking beyond 'prostitution'. African Studies. 2002; 62:99-120.

Hunter M. Cultural politics and masculinities: multiple-partners in historical perspective in KwaZuluNatal. Culture, Health and Sexualities. 2005; 7(3):209-223.

Kishindo P. Sexual behavior in the face of risk: The case of bargirl in Malawi's major cities. Health Transition Review. 1995; 5:153-160. Supplement to.

Kulick, D. Travesti: Sex, gender, and culture among Brazilian transgendered prostitutes. Chicago: University of Chicago Press; 1998.

Kydd J, Christiansen R. Structural change in Malawi since independence: consequences of a development strategy based on large-scale agriculture. World Development. 1982; 10(5):355-375.

Laclau, E., Mouffe, C. Hegemony and state socialism: Towards a radical democratic politics. London: Verso; 1985. 
Mair LP. Marriage and family in the Dedza district of Nyasaland. Journal of the Royal Anthropological Institute of Great Britain and Ireland. 1951; 81(1-2):103-119.

Mandala E. Capitalism, kinship and gender in the lower Tchiri (Shire) valley of Malawi, 1860-1960: an alternative theoretical framework. African Economic History. 1984; 13:137-169.

Mauss, M. The gift: The form and reason for exchange in archaic societies. London: Routledge; 1990 [1923-24].

Mitchell, JC. The Yao village: A study in the social structure of a Malawian tribe. Manchester: Manchester University Press; 1956.

Murphy AK, Venkatesh SA. Vice careers: the changing contours of sex work in New York City. Qualitative Sociology. 2006; 29(2):129-155.

Peters PE. Against the odds: matriliny, land and gender in the Shire highlands in Malawi. Critique of Anthropology. 1997; 17(2):189-210.

Poulin, MJ. PhD dissertation. Department of Sociology, Boston University; Boston, MA: 2006. The sexual and social relations of youth in rural Malawi: Strategies for AIDS prevention.

Poulin MJ. Sex, money, and premarital partnerships in southern Malawi. Social Science and Medicine. 2007; 65(11):2383-2393. [PubMed: 17764797]

Price K. Keeping the dancers in check: the gendered organization of stripping work in the Lion's Den. Gender and Society. 2008; 22(3):367-389.

Rosenthal P, Peccei R. The social construction of clients by service agents in reformed welfare administration. Human Relations. 2006; 59:1633-1658.

Strauss, A., Corbin, JM. Basics of qualitative research. Newbury Park: Sage; 1990.

Swidler, A. Talk of love: How culture matters. Chicago: University of Chicago Press; 2001.

Swidler A, Watkins SC. Ties of dependence: AIDS and transactional sex in rural Malawi. Studies in Family Planning. 2007; 38(3):147-162. [PubMed: 17933289]

Tavory I, Swidler A. Condom semiotics: meaning and condom use in rural Malawi. American Sociological Review. 2009; 74(2):171-189.

Trotter H. Navigating risk: lessons from the dockside sex trade for reducing violence in South Africa's prostitution industry. Sexuality Research \& Social Policy. 2007; 4(4):106-119.

Trotter, H. Sugar girls and seamen: A journey into the world of dockside prostitution in South Africa. South Africa: Jacana Media; 2008.

van den Borne, F. Trying to survive in times of poverty and AIDS: Women and multiple partner sex in Malawi. Amsterdam: Het Spinuis; 2005.

van den Borne F. Using mystery clients to assess condom negotiation in Malawi: some ethical concerns. Studies in Family Planning. 2007; 38(4):322-330. [PubMed: 18284046]

Weitzer, R. Why we need more research on sex work. In: Weitzer, R., editor. Sex for sale: Prostitution, pornography and the sex industry. New York: Routledge; 2000. p. 7-32.

White, L. The comforts of home: Prostitution in colonial Nairobi. Chicago: University of Chicago Press; 1990.

Wojcicki JM. Commercial sex work or Ukufandha? Sex-for-money exchange in Soweto Hammanskraal area, South Africa. Culture, Medicine and Psychiatry. 2002; 26:339-370.

World Bank. World development indicators database. 2005. Available online at http:// devdata.worldbank.org/external/CPProfile.asp?CCODE=MWI\&PTYPE=CP

Zelizer VA. The social meaning of money: 'special monies'. American Journal of Sociology. 1989; 95(3):342-377.

Zelizer, VA. The social meaning of money. New York: Basic Books; 1994.

Zelizer, VA. Intimate transactions. In: Guillen, MF.Collins, R.England, P., Meyer, M., editors. The new economic sociology: Developments in an emerging field. New York: Russell Sage; 2002. p. 274-300.

Zelizer, VA. The purchase of intimacy. Princeton: Princeton University Press; 2005. 